\title{
The Negative Effect of Time Budget Pressure to Auditor Independence and Professional Skepticism
}

\author{
Andi Ina Yustina ${ }^{1 *}$, Stephanie Angelica Gonadi ${ }^{2}$ \\ Accounting Department, President University \\ Jababeka Education Park, Л. Ki Hajar Dewantara, Jababeka, Cikarang, Bekasi 17550, Indonesia \\ ${ }^{*}$ Corresponding author; Email: a.inayustina@gmail.com
}

\begin{abstract}
This research examines whether time budget pressure affects professional skepticism and if so, whether the effect is mediated by auditor independence or not. A web-based survey is used to deliver questionnaires to 163 auditors from big four and non-big four public accounting firms in Jakarta. The result shows that auditor independence (AI) partially mediates the relationship between time budget pressure (TBP) and professional skepticism (PS), which means that external auditors in Jakarta who experience high time pressure tend to decrease their independence and resulted in deep skepticism. Seeing this result, this study suggests to increase the number of audit team members, set the number of minimum supporting evidence, and have a supervisor to monitor auditor's job, as it will help to minimize the negative effect of time pressure.
\end{abstract}

Keywords: Time budget pressure; auditor independence; professional skepticism; auditor; public accounting firm; JEL classification; M410; M420.

\section{INTRODUCTION}

A financial statement is crucial information that presents the condition of a business. Through this information, shareholders will be able to know the performance of a company and see its appropriateness. To make sure of the reliability of a financial statement, auditor helps stakeholder and shareholder to check if the financial statement is fairly presented or not [40]. Therefore, the responsibility of the auditor is ".... to plan and perform the audit to obtain reasonable assurance about whether the financial statements are free of material misstatement, whether caused by error or fraud' [1] [41].

Hence, in doing their responsibility, it is crucial for auditors to maintain their professionalism. [45] said that the notions of professional ethics drive auditors' behaviors. Which means, in doing their responsibility auditors must be in line with professional conduct. Therefore, professionalism is essential in auditing. In that case, auditor behavior is also as important as work methods or technical competence [19]. Thus, some rules and regulations are already settled to maintain audit quality and protect shareholders, such as the ISA (International Standard Auditing) and GAAS (Generally Accepted Auditing Standard).

Many researchers found that audit quality can be affected by auditor independence and professional skepticism [8] [24]. This shows that inde- pendence and skepticism are essential factors in auditing practice. Another research shows that it is crucial for the auditor to maintain independence, because if an auditor lacks independence, the auditor will not do an audit objectively, and therefore, professional skepticism cannot be met [24]. Therefore, auditor independence is in line with professional skepticism. Another professional standard also requires auditors to maintain their skepticism while conducting the audit [15] [16]. Even so, lots of audit scandals that happen because of the auditor's lack of independence and skepticism, for example, the case of Arthur Andersen and the case of British Telkom. Hence, this study argues that there is another factor that affecting auditor's independence and skepticism.

According to [23], professional skepticism is divided into six components, which are: a search for knowledge, suspension of judgment, self-determining, interpersonal understanding, self-confidence, and questioning mind. This study will focus on questioning mind, interpersonal understanding and suspensions of judgment, with some reasons. First, questioning mind because [10] and [11] stated that professional skepticism includes a questioning mind. Based on the standards, questioning mind includes being alert of possible misstatement or fraud that might occur. Which means that questioning mind is an essential factor that auditors must have. The example of questioning mind is seeking clarification or proof from 
clients by asking 'How do you calculate your expenses?'

The second reason is the interpersonal understanding. [36] stated that understanding people's motivations and behaviors are the fundamental components of skepticism, which means that by following people an auditor will be able to recognize their client's perceptions towards an event or evidence. Additionally, [23] explained that interpersonal understanding could help auditors to evaluate evidence, which means that it can help the auditors to understand the motivation and integrity of the evidence. Hence, it is vital to the auditor to have interpersonal understanding in auditing.

Last reason is a suspension of judgment. [30] stated that an auditor should gather enough evidence before making a judgment, which means judgment must be suspended until competent evidence is discovered. Moreover, auditing standard also states that "the auditor should not be satisfied with less than persuasive evidence" [10] which means that the rule requires an auditor to obtain more evidence. Consequently, it will prevent the auditor from making the wrong judgment. Therefore, suspend judgment to find a reliable indication, so that creates a relevant audit report.

Another factor that can affect audit quality is stress or pressure. [4] noted that the number of audit work that continues increase would decrease audit quality. Similarly, stress has a physiological and behavioral effect which lead to poor job performance [49]. Hence, stress or pressure becomes an issue in auditing practice. Furthermore, tensions in the audit process, such as the time budget pressure, can lead to severe consequences [46]. Time budget in auditing becomes a performance measurement, which creates a burden to the auditor in maintaining the high quality of audit which took lots of time and met the targeted audit deadline. [47] claimed that if the time given in doing a review is increased, then the audit quality is also increasing. Which shows that time budget pressure can become a factor that affecting auditor independence and professional skepticism.

Therefore, the motivation of this study is, first, to expand the research of [24] which still requires further research on the relationship of time pressure with professional skepticism, as they stated on p. 62-63:

“...other areas related to external environmental characteristics that might have an impact on an auditor's professional scepticism is the potential issues arising from time pressure".

The second motivation is to extend the research of [8] to get a better understanding of factors that can be affecting auditor independence and professional skepticism. However, the study of [8] did not examine the role of time budget pressure in their studies. Whereas, time budget pressure has an essential role in affecting decision making [14] which destabilize independency. The studies of [2] [6] [12], and [35] also stated that time budget pressure is lowering audit quality. This study argues that auditors that experienced time budget pressure will tend to have an audit quality reducing behavior which is accepting weak client explanation. Hence, time budget pressure becomes an important factor that can be considered in auditing. Then, the study of [6] concluded that time budget pressure is speculated to influence auditor independence. Which means, if an auditor experiences time pressure, which makes them focus more on meeting deadline, then it is possible that their independence will decrease. Therefore, consequently, if an auditor lacks independence it will reduce his/her professional skepticism [24]. Hence, it makes auditor independence mediates the relationship between time budget pressure and professional skepticism.

\section{Time Budget Pressure}

In auditing, time budget pressure can be interpreted because of the audit firm and auditor attempted to lower audit fees and try to give service to client [6] [17]. As a result, it creates pressure on the auditor to meet the time budget. The study of [27] said that time budget pressure could increase auditors' stress level and as a result, it will reduce their job performance. Auditor time budget can be tightened, this could happen when auditors use their spare time to complete their work to meet the targeted deadline and do not report the actual time that they spent on the audit process [6]. If the auditor says less time than the budgeted time, then the time budget can be tightened in the future, which create more pressure on the auditor[39]. According to [20], those pressure may cause auditors to fail in performing their expected work. Even more, time pressure can cause auditors to behave unprofessionally [37].

Consequently in a respond to time budget pressure, first, auditor behavior tends to reduce the audit quality, such as accepting client statement as it is [5] [17]. Second, the auditors will do premature sign-offs [47]. Hence, both consequences can lead to audit quality reduction [6].

\section{Auditor Independence}

Independent means neutral or free from outside control or not depending on another's authority. Based on [48], independence in auditing is taking unbiased viewpoint when auditing. Accor- 
dingly, an independent auditor means that the auditor only makes a decision based on the fact and rely on the auditing standard. Meanwhile, based on professional auditing standard; auditor independence is a necessary thing that the auditors should have. With independence, auditors will be able to work with integrity and objectivity. Hence, in doing their job, auditors must be independent.

Auditor independence becomes a critical factor in auditing practice. Many scandals happen because of auditor's lack of independence. One of the most considerable scandals is Enron Corporation and Anderson, LLP. Since this scandal gives a lot of losses, the Sarbanes Oxley Act is made to mitigate any fraudulent risk.

Based on the study of [30], auditor independence divided into two components. The first component is the practitioner's independence; this component reveals that independence came from the individual characteristics of auditors to work with integrity and objectivity. The second component is professional independence, which states that auditors are presented as a group of expert to the public, this will not only increase the public's trust but also ensure the continuity of the global accounting firm. Therefore, it is essential for auditors to maintain both components.

\section{Professional Skepticism}

Professional skepticism is an essential criterion that auditors must have. Professional standards also regulate the importance of auditors being skeptical. SAS No.1 stated that "Due professional care requires the auditor to exercise professional skepticism”. According to [35], professional skepticism is someone's behavior that doubts a statement. This behavior will be useful for the auditors to identify the indication of fraud [24]. Therefore, professional skepticism is needed in doing audit practice.

A questioning mind is one of the parts in skepticism [23]. Based on that studies, questioning mind means behavior that includes investigating, verifying, active questioning and curiousness. The study of [35] also argued that questioning mind is the activity of examining possible conclusion. Which means, while doing an audit, the auditor cannot directly accept the client's statement without any reliable evidence. In practice, the example of questioning mind is by asking "what do you mean?" and "why do you believe what you do?". Therefore, in auditing, the questioning mind is an act of being conscientious for possible misstatement, error or fraud. The rules of verification that require auditors to maintain their skepticism are also stated in the Statement on Auditing Standard No.82 and No. 99. Hence, auditors should have a questioning mind to support skepticism [10] and [11].
From a psychological aspect, the theory of mind, another part of skepticism is interpersonal understanding, which means understanding someone else by knowing the reason of why someone acts in a certain way [3]. While in accounting practice, interpersonal understanding is the ability of someone to understand the intention of fraudulent activity through individual aspect [23]. Generally, interpersonal understanding is how people can understand others.

According to [23], interpersonal understanding is a part of skepticism, because it deals with the individual in providing evidence. It shows that, when auditor examines the audit evidence, the auditor will look for the motivation or perception of their client, so that it will provide accurate audit evidence. Thus, by having interpersonal understanding, the auditor will be more skeptical. Additionally, [7] argued that skepticism is seen as imperative characteristics that should be embeded in the auditor.

Another part of professional skepticism is the suspension of judgment. Suspension of judgment is eager for someone to get a clear explanation or proof about an event before the auditor makes a judgment [28]. Accordingly, in auditing practice, suspension of judgment means that the auditor needs to find enough evidence before making any decision. The study of [23] showed that suspension of judgment is part of skepticism. [34] stated that to be a fully developed skeptic, someone needs to establish a suspension of judgment. Therefore, to be skeptical, the auditor must possess suspension of judgment.

\section{Hypotheses Development}

\section{Time budget pressure and auditor indepen- dence}

As mentioned previously, the purpose of being independent is to uphold professional skepticism $[8,24]$. The need for professional auditors to maintain independence while doing their job is also stated in the IASB, which shows that the auditors must have an independent attitude. The reason behind this statement is because auditor independence is an indicator that set the auditors' performance in doing their responsibility. In other words, if the auditors have high independence, then they tend to do their job correctly.

Whereas, the study of [6] stated that time pressure can affect auditor performance in doing their job. It decreases auditor independence because time pressure can increase the tension that the auditors feel in order to meet their deadline. With this tension, auditors tend to prioritize to meet the targeted timeline, which leads them to be 
quickly affected by their client. Therefore the hypothesis is:

H1: Time budget pressure has a negative effect on auditor independence.

\section{Auditor Independence with professional skep- ticism}

First, this study discusses the relation between auditor independence and questioning mind. According to [23], the questioning mind is part of professional skepticism, which related to the way the auditor examines the evidence. Having a questioning mind means that auditors have the tendency to questioning a statement until they find a shred of appropriate evidence. Based on the study of [8] [30], auditor independence will increase the ability of auditor in doing their job with integrity, objectivity and conserve professional skepticism. Which means that if the auditors are not independent, the strength of auditor in professional skepticism will decrease.

Second, interpersonal understanding is also the part of skepticism, which shows from the human aspect [23]. According to [33], auditor's interpersonal understanding can be used to identify their client using social skills, which means, if the auditor has a close relationship with their client, then it is easier for auditors to have understanding toward their clients. When an auditor has close relationships with their client, it decreases their independence and makes their interpersonal understanding to be doubted [32]. In other words, having a close relationship with their client can help the auditor to increase their interpersonal understanding, yet this must be balanced with high independence.

Another part of skepticism is the suspension of judgment which is related to the way auditor examine the evidence [23]. Having suspension of judgment characteristics means that the auditor will refuse to decide before they satisfied with the evidence. In examining the evidence, if auditors are affected by their client and cause them to fail in maintaining their independence, then it is impossible that they can instil the value of skepticism [24]. Hence, auditor independence will increase the ability of the auditor to be skeptical. Therefore, the hypothesis is:

H2: Auditor independence has a positive impact on professional skepticism.

\section{Time budget pressure, Auditor independence, and professional skepticism}

The professionalism of auditor, which is being independent, is affected by time budget pressure [37]. Based on [29], time budget pressure happens once a public accounting firm sets an insufficient number of hours for auditors to complete an audit procedure. Which means, the time that given to do the audit process is not proportionate to the quantity of work.

However, since the auditors attempt to meet the targeted deadline, then they tend to perform dysfunctional behavior [20] [38]. Therefore, time budget pressure will decrease auditor independence. Hence, auditor independence is being lowered, and it is impossible for auditors to be skeptical [24]. Thus, the researcher suggests the following hypothesis:

H3: Auditor independency mediates the relationship between time budget pressure and professional skepticism.

\section{Research Model}

Based on the literature and hypothesis development above, the researcher constructs the graph below to find the relation between time budget pressure as an independent variable, auditor independence as a mediating variable, and professional skepticism as a dependent variable.

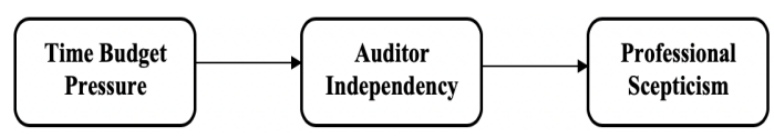

Figure 1. Research Model

\section{RESEARCH METHOD}

\section{Sampling Design}

The target population of this study is the external auditors in Jakarta who work in PwC, Deloitte, EY, KPMG, and non-Big Four from all position. The sample is taken using a purposive sampling method. The purposive sampling method is a nonprobability sampling technique, which refers to non-random sampling. It means, in choosing the samples, the researcher is considering the criteria and characteristics that are suitable for the research. Hence, this sampling technique gives relevant information to the study.

The type of data used in this study is primary data, which means that the information used in this study is gained from its source [43]. In this study, primary data is being collected through a questionnaire using the Likert Scale. The data source is the external auditors in Jakarta-Indonesia.

In determining sample size, this study uses [21]'s requirements, which stated that for each question in the questionnaire the researcher must collect five respondents. This study consists of an independent variable, a dependent variable and a 
mediating variable, with a total of 20 questions. As required by [21], the minimum sample for a/this research is 100 respondents.

\section{Variables}

The independent variable used in this research is time budget pressure. Time budget pressure is measured by using questionnaires adapted from [31]. Each statement is scored by using a Likert scale from 1 to 5 (1=strongly disagree, $5=$ strongly agree). The example of the question is "I usually finish my work within the allotted time."

The dependent variable of this research is professional skepticism using a questionnaire adapted from [23]. Each statement is scored using a Likert scale from 1 to 5 (1=Strongly Disagree, $5=$ Strongly Agree). The example question is "My friends tell me that I never question things that I see or hear."

The mediating variable of this research is auditor independence. Auditor independence is measured using a questionnaire adapted from [50]. Each statement is scored using a Likert scale from 1 to 5 (1=Strongly Disagree, $5=$ Strongly Agree). The example of the question is "I have a close relationship with some of my clients."

\section{Research Instrument}

This study uses survey methods for collecting data. This method uses a questionnaire that will be filled by respondents through a google form. The procedure that we used for distributing the questionnaire is based on [13]. This questionnaire has two main sections, the first section consists of questions about the variable that is measured using the 5 Likert Scale. The second section consists of items regarding respondents' personal and demographic data including age, gender, workplace, and position. Thus, there is a total of 24 questions - this questionnaire is being distributed through social media such as LinkedIn and WhatsApp.

Since all populations of this study are located in Jakarta and in order to create more convenience and understanding to the respondents, this questionaire is available in two languages: Indonesian and English. This research conducts the randomization and reversal of questions. The researcher believes that the respondents should complete filling the questionnaire independently and conveniently, which will increase the accuracy and relevance of the data. To improve the questionnaire and avoid some errors, before the questionnaire is distributed to the real samples, the researcher conducts a pilot test. The questionnaire is distributed to accounting students at President University who have taken an internship as an auditor. Thus, the respondent of pre-testing questionnaire can give appropriate comments and criticism to improve the questionnaire.

\section{Statistical Analysis}

The statistical technique used in this study is the Structural Equation Model (SEM) tool with Partial Least Squares (PLS). SEM is an extension of multivariate analysis that can be used to analyze the latent variable. There are also advantages offered by this application, and the first is testing a complex research model simultaneously and being able to examine variables that cannot be measured directly and consider the measurement errors [21]. [42] also stated that SEM can handle a study with small sample size and complex structure. Accordingly, since SEM is suitable for this study, then SEM-PLS is used. The software used in this research is Warp PLS software (Version 3.0).

\section{RESULT AND DISCUSSION}

\section{Respondent's Profile}

This research obtains its respondents through social media and sending e-mails to auditors from Big Four and non-Big Four Public Accounting Firms. The auditors who fill up the online surveys are all from Jakarta Branch Offices. The researcher asks about the demographic data of the respondents such as their age, gender, work experience, and job position. A total of 250 questionnaires are distributed to the auditors from associate level to supervisor level, but only 163 auditors respond and complete the questionnaires. Thus, the response rate of this study is $65.2 \%$. From those 163 respondents, $69 \%$ are male, and $31 \%$ are female. The majority of the respondents is $22-26$ years old group with $73 \%$, while $27-31$ years old is $18 \%, 32-36$ years old is $6 \%, 37-41$ years old is $2 \%$, and only $1 \%$ respondent at the age above 42 years old. Among this respondent, $44 \%$ of them have three months to a year of work experience, $36 \%$ have $2-4$ years of work experience, $12 \%$ have more than seven years of work experience, and $8 \%$ with 5-7 years of work experience. Next is the position of the respondents, $33 \%$ of them are junior auditors, $29 \%$ are associate auditors, $21.5 \%$ are senior auditors, $10.4 \%$ are audit managers, and $6.1 \%$ are audit supervisors. The percentage of the respondents is 51\% from Big Four and 49\% from non-Big Four. The details of the respondents demographic are presented in Table 1.

\section{Descriptive Analysis}

Table 2 presents the means, standard deviations, and correlation among study variables. The result indicates that time budget pressure has a 
negative relationship with auditor independence (B $=-0.41, \mathrm{p}<0.01)$. The outcome between the ties of auditor independence and professional skepticism shows a positive correlation $(B=0.61, \mathrm{p}<0.01)$.

Table 1. Demographic details of respondents

\begin{tabular}{llc}
\hline \multicolumn{2}{c}{ Description } & \% of respondents \\
\hline Gender & Male & $69 \%$ \\
& Female & $31 \%$ \\
& & \\
& $22-26$ & $73 \%$ \\
$27-31$ & $18 \%$ \\
$32-36$ & $6 \%$ \\
$37-41$ & $2 \%$ \\
$>42$ & $1 \%$ \\
Experience & \\
3 months -1 year & $44 \%$ \\
$2-4$ years & $36 \%$ \\
$5-7$ years & $8 \%$ \\
& $>7$ years & $12 \%$ \\
Position & \\
Associate & $29.0 \%$ \\
Junior & $33.0 \%$ \\
Senior & $21.5 \%$ \\
Manager & $10.4 \%$ \\
Supervisor & $6.10 \%$ \\
Big Four & \\
Non- Big Four & $51 \%$ \\
\hline
\end{tabular}

Table 2. Descriptive statistics and correlations

\begin{tabular}{lccccc}
\hline & Mean & SD & TBP & AI & PS \\
\hline Time Budget Pressure & 2.820 & 1.140 & $-0.41^{* * *}$ & \\
(TBP) & & & & \\
Auditor Independence (AI) & 3.578 & 1.142 & & $0.61^{* * *}$ \\
Professional Skepticism & 2.969 & 1.075 & & \\
(PS) & & & & \\
${ }^{* * k}$ Significant at $p<0.01$ & & & &
\end{tabular}

\section{Inferential Analysis}

\section{Validity and Reliability Test}

Doing a validity and reliability test for the research data is very important. In this research, validity can be assessed with testing the convergent and discriminant among each construct. Based on [21], convergent validity can be evaluated by considering two factors: Factor Loadings and Average Variance Extracted (AVE). If the value of the loading is higher than 0.5 and 0.7 , the convergent validity is considered to be reached [21]. Therefore, several items in this research from professional skepticism and auditor independence are deleted because their loading value is less than 0.4 , while indicators with loadings between 0.5 until 0.7 should be considered [21]. The consideration in the indicator deletion is based on the effect that influences the Average Variance Ex- tracted (AVE) and composite reliability to meet the standard required. When the elimination of the indicator does not increase AVE and composite reliability above the standard requirement, it is better to keep the indicator rather than to delete it. The deletion item is from AI [11] "I do not care about the fate of my clients". From Professional Skepticism is [3], "I would like to understand the reason for other people's behaviour", [6] "I do not take time when making decisions" and [8] "I dislike having to make decisions quickly".

The total indicators used in this analysis are 16 items and the result can be seen in Table 3 . From the 16 questions, 15 have the factor loadings higher than 0.7, and one has the factor loading exceeding 0.5. All of the indicators have met the acceptable standard of AVE which is above 0.5. In summary, all shreds of the evidence above indicate that the convergent validity of the measurement model is qualified. Based on [44] measuring the reliability, the researcher can use two measurements: composite reliability and Cronbach's alpha. The requirement for both composite reliability (CR) and Cronbach's alpha should be higher than 0.70 . As shown in Table 3, the values of the composite reliabilities of each variable are higher than the accepted values of 0.70 . Based on [21], the acceptable standard for Cronbach's alpha is above 0.70. Therefore, Auditor Independence (AI), Time Budget Pressure (TBP) and Professional Skepticism (PS) have already met the standard requirement.

Table 3. Reliability and convergent validity

\begin{tabular}{|c|c|c|c|}
\hline Latent Variable & Mean & SD & Loading \\
\hline \multicolumn{4}{|c|}{$\begin{array}{l}\text { Time Budget Pressure (TBP) (AVE }=0.639 ; \text { Composite } \\
\text { Reliability }=0.841 ; \text { Cronbach's Alpha }=0.714)\end{array}$} \\
\hline TBP 1 & 2,759 & 1.115 & $(0.850)$ \\
\hline TBP 2 & 2,685 & 1.151 & (0.709) \\
\hline TBP 3 & 3,016 & 0.969 & $(0.831)$ \\
\hline \multicolumn{4}{|c|}{$\begin{array}{l}\text { Auditor Independence (AI) (AVE }=0.791 \text {; } \\
\text { Reliability }=0.919 \text {; Cronbach's Alpha }=0.868)\end{array}$} \\
\hline$\overline{\mathrm{AI}} 1$ & 3.555 & 1.105 & (0.895) \\
\hline $\mathrm{AI} 2$ & 3.648 & 1.157 & $(0.886)$ \\
\hline $\mathrm{AI} 3$ & 3.530 & 1.160 & $(0.886)$ \\
\hline \multicolumn{4}{|c|}{$\begin{array}{l}\text { Professional Skepticism (PS) (AVE }=0.581 ; \\
\text { Reliability }=0.932 ; \text { Cronbach's Alpha }=0.918)\end{array}$} \\
\hline PS 1 & 3.104 & 1.163 & (0.577) \\
\hline PS 2 & 3.024 & 0.974 & (0.763) \\
\hline PS 3 & 2.907 & 1.011 & $(0.776)$ \\
\hline PS 4 & 2.870 & 1.106 & (0.819) \\
\hline PS 5 & 2.703 & 1.035 & $(0.857)$ \\
\hline PS 7 & 3.055 & 1.090 & $(0.786)$ \\
\hline PS 8 & 2.728 & 1.083 & (0.813) \\
\hline PS 10 & 2.975 & 1.105 & $(0.836)$ \\
\hline PS 12 & 3.141 & 1,041 & $(0.701)$ \\
\hline PS 13 & 3.179 & 1.011 & $(0.651)$ \\
\hline
\end{tabular}


Discriminant validity is measured by comparing the square roots of average variance construct (AVE) with the correlations among latent variables. The square roots of AVE are indicated in the diagonal element and bracketed. [18] stated that discriminant validity is fulfilled if the value of the square root of the AVE is higher than the correlation between other latent variables in the same column (above or below it). As an example, the latent variable "Time Budget Pressure (TBP)" has the square root of AVE 0.799 which is higher than the correlation of latent variable that is in the same column of TBP which are -0.286 and -0.531 . Hence, it provides evidence with sufficient discriminant validity. Consequently, the result which is presented in Table 4 reveals that the discriminant validity is met because all square roots of the AVE (on the diagonal and bracketed) are higher than the correlation between another construct (in the off-diagonal).

Table 4. Discriminant Validity

\begin{tabular}{lccc}
\hline & TBP & AI & PS \\
\hline Time Budget Pressure (TBP) & $(0.799)$ & & \\
Auditor Independence (AI) & $-0.286^{* * *}$ & $(0.889)$ & \\
Professional Skepticism (PS) & $-0.531^{* * *}$ & $0.577^{* * *}$ & $(0.763)$ \\
\hline Diagonal element: square root of AVE; off-diagonal: corre- \\
lation between constructs. & & & \\
${ }_{* * *}$ Significant at $p<0.01$ & & &
\end{tabular}

\section{Structural Model Analysis}

In performing structural model analysis, the researcher identifies the direct effect between Time Budget Pressure (TBP) as an independent variable to Professional Skepticism (PS) as the dependent variable. The researcher does not include the mediating variable which is auditor independence in the model. The objective to test this is to know whether time budget pressure affects professional skepticism to auditors directly. The result shown in Table 5 indicates that time budget pressure (TBP) has a significant impact on professional skepticism (PS) because all $\mathrm{p}$-value is less than 0.01. Time Budget Pressure (TBP) $(B=-0.53)$ has a negative relationship and significantly related to professional skepticism.

On evaluating the mediating effect, the researcher conducts further analysis for analyzing auditor independence as a mediating variable between both items of time budget pressure and professional skepticism. The model and its result are shown in Table 5. The results reveals that time budget pressure (TBP) affects auditor independence negatively $(B=-0.41, \mathrm{p}<0.01)$. Result also shows that auditor independence is positively related to professional skepticism $(B=0.51, \mathrm{p}<$ $0.01)$. The $R$ squared for TBP to auditor indepen- dence is 0.17 which means that for time budget pressure, only $17 \%$ out of $100 \%$ have a significant impact than other existed variables related to auditor independence. Meanwhile, time budget pressure to professional skepticism has $\mathrm{R}$ squared of 0.52 , which means this variable has a $52 \%$ significant impact other than existed variables related to professional skepticism. According to [44] measuring the mediating role with WarpPLS is by comparing the direct effect without mediating variable and with the existence of the mediating variable. The result shows that auditor independence has partially mediated time budget pressure to professional skepticism $(B=-0.40, \mathrm{p}<0.01)$.

Table 5. PLS result

\begin{tabular}{|c|c|c|c|}
\hline \multirow[b]{2}{*}{ Variable } & \multicolumn{3}{|c|}{ Path to } \\
\hline & $\begin{array}{c}\text { Time } \\
\text { Budget } \\
\text { Pressure }\end{array}$ & $\begin{array}{c}\text { Auditor } \\
\text { Indepen- } \\
\text { dence }\end{array}$ & $\begin{array}{l}\text { Professional } \\
\text { Skepticism }\end{array}$ \\
\hline \multicolumn{4}{|l|}{ Direct } \\
\hline Time Budget & & & \multirow{4}{*}{$-0.53^{\text {tren }}$} \\
\hline Pressure (TBP) & & & \\
\hline Mediating & & & \\
\hline Time Budget & & & \\
\hline Pressure (TBP) & & $-0.41^{\text {*k+k }}$ & $-0.40^{* \ldots+k}$ \\
\hline Auditor & & & $0.51^{* k+k}$ \\
\hline Independence (AI) & & 0.17 & 0.52 \\
\hline \multicolumn{4}{|l|}{$\mathrm{R}^{2}$} \\
\hline \multicolumn{4}{|l|}{ Full Model } \\
\hline \multicolumn{4}{|l|}{ Time Budget } \\
\hline Pressure (TBP) & & $-0.41^{* *+k}$ & $0.61^{\text {*k- }}$ \\
\hline \multicolumn{4}{|l|}{ Auditor } \\
\hline Independence (AI) & & 0.17 & 0.38 \\
\hline $\mathrm{R}^{2}$ & & & \\
\hline
\end{tabular}

The hypothesized model is shown in Figure 5. Results reveal that time budget pressure has correlation and insignificant relationship with auditor independence $(B=-0.41, \mathrm{p}<0.01)$. Thus, hypothesis 1 is supported, which means that time budget pressure has negatively related to auditor independence is supported. The $\mathrm{R}$ squared for time budget pressure has 0.17 or $17 \%$ out of $100 \%$ significant impact on affecting auditors' independence. Result supported hypothesis 2 states that auditor independence has positive effect related with professional skepticism $(B=0.61, \mathrm{p}<0.01)$ and auditor independence is the variable that has a significant impact to professional skepticism with $38 \% \mathrm{R}$ squared.

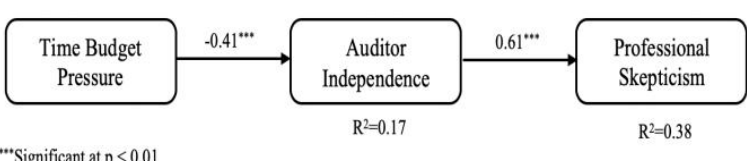

Figure 2. Full PLS Model 
Further analysis to test auditor independence as a mediating variable, this study used the VAF test (Variance Accounted For). According to [22] VAF test is more powerful than Sobel's test. If the VAF value is above 80 percent, it means full mediation, but if it is between 20 percent and 80 percent, the mediation effect is partial, and if the value is less than 20 percent, it means the impact is minimal, which means that there is no mediation. As shown in table 6, auditor independence has a partial effect on time budget pressure and professional skepticism.

Table 6. VAF (Variance Accounted For)

\begin{tabular}{lcc}
\hline \multicolumn{1}{c}{ Description } & \multicolumn{2}{c}{ Calculation } \\
\hline Indirect Effect (TBP-AI-PS) & $-0.410 \times 0.510$ & -0.209 \\
Direct Effect (TBP-PS) & & -0.530 \\
Total Effect & & -0.739 \\
\hline VAF for TBP-AI-PS & $-0.209 /-0.739$ & $\mathbf{0 . 2 8 3}$ \\
\hline
\end{tabular}

\section{Discussion and Implication}

This study examines the relationship of time budget pressure on professional skepticism and auditor independence as the mediating variable. In this study, auditors from big four and non-big four accounting firms act on behalf of the respondents. It is known that an external auditor is a highpressure job. This pressure can occur from the willingness of auditor to meet the targeted audit deadline. Though, this pressure can lead to the failure of the auditors to do the job that is expected from them. Therefore, one of the forces in public accountant firm is the time budget. Based on the [6] and [17], time budget pressure can happen because of the public accounting firms want to reduce the audit fee so that their client keeps using their service.

Consequently, with the time that has already been budgeted and a load of work, auditor becomes depressed. However, since meeting the targeted audit deadline is essential and combined with this high-pressure situation, auditors tend to become not independent and easily affected by their client. Hence, this research shows that high time pressure that usually happens in the "busy-season" does affect the auditor and makes them suffer. As a result, the auditor's independence in Jakarta can be affected. Therefore, the first hypothesis is supported.

The second hypothesis is also supported, which is related to the relation of auditor independence and professional skepticism. The reasonable logic behind this result is, professional skepticism itself is an auditor skill in analyzing and prove the reliability of evidence. Meanwhile, auditor independence is the auditors' ability to do their job with integrity and maintain objectivity. Which means, auditor independence controls how the auditors act in doing their job. This is because independence is an attitude of the auditor that cannot be influenced by others while skepticism is an attitude of not easily believing a statement. In other words, if auditors' independence is decreasing, it makes them be influenced by their client, and thus it will be hard for an auditor to maintain fair skepticism. Hence, it is showing that to be able to maintain professional skepticism, and the auditor should be independent. Therefore, auditor independence has a positive relationship with professional skepticism. This means that external auditor in Jakarta who can maintain their independence will have high skepticism. The results prove the studies from [8] and [24], who mentioned that professional skepticism can happen if the auditor is independent. Thus, the auditors can find any misstatements or errors during an audit.

This study also shows the direct relationship between time budget pressure and professional skepticism. The result shows a negative association with this variable. Which means, when auditors experienced time tightness, they do not prioritize evidence, since upholding the skepticism means they are required to find more evidence, as the consequence of being skeptical is that it takes lots of time. In other words, time pressure can decrease auditor's job effectiveness because they will have less collection of evidence. This result means, in the purpose of meeting the audit deadline and with the load of work, the external auditor in Jakarta will feel pressure and tend to be less skeptical. Therefore, time budget pressure gives a negative effect on professional skepticism.

This study also proves the mediating relationship of auditor independence between the relation of time budget pressure and professional skepticism. It is because auditor independence is influenced by time budget pressure, which resulted in weak auditor independence when there is high time budget pressure. Thus, since auditor independence and skepticism have a positive relationship, accordingly it will result in low professional skepticism. This means the external auditors in Jakarta who have limited independence as a result of experiencing high time pressure will tend to be not skeptical.

In summary, the results of the study on time budget pressure variables that are suspected of having a negative impact on auditor independence and professional skepticism turn out showing a significant relationship. Which means, an auditor who suffers by the time pressure can be less independent and skeptical. Moreover, this study also shows how important it is for auditors to uphold their independence and being skeptical. 
Therefore, this study proposes that public accountant firms should give more considerations on the selection of audit time deadline or finding an alternative to increase auditor independence and professional skepticism.

Seeing the result, this study proposes several ways that can be used to mitigate the negative effect of time budget pressure, such as increasing the number of an audit team member. This study believes that by increasing the number of auditors, the work done will be lighter and the tension caused by time pressure will be decreased. The other suggestion is to set a standard of a minimum of supporting evidence. This study believes that setting the minimum number of supporting evidence will increase professional skepticism. However, above all, a public accounting firm should have an independent supervisor to monitor their auditor.

\section{CONCLUSION}

This study examines the impact of time budget pressure (TBP) on professional skepticism (PS) and auditor independence as the mediator. Hypotheses are tested with 163 auditors from big four and non-big four in Jakarta. The hypothesis statements have been verified with Structural Equation Modelling-Partial Least Square (SEM-PLS). The outcome of all hypotheses shows that time budget pressure has a negative relationship to auditor independence, and as the consequences, it will also lower professional skepticism. Furthermore, auditor independence does mediate the relationship between time budget pressure and professional skepticism.

This study also contributes to behavioral accounting works of literature by examining time budget pressure towards auditor. The decision in setting time budget for auditing process does affect the auditor behavior. This study shows that tight time budget can create pressure to the auditor, which then leads to a failure in maintaining their professionalism, such as being independent and skeptical. According to [6], the tight time budget is not without reason, but because of the accounting firms' desire to keep their clients. Therefore, this creates a contradiction between maintaining the client and uphold independence and skepticism.

Based on the result of the study, time budget pressure has a significant role in auditing practice. Thus, it is crucial for a public accounting firm to reduce time budget pressure. Since time budget pressure is used for future decisions such as the basis of the budget for the next year, the evaluation of the auditor's performance, and the determination of audit fees [37]. Therefore, the manage- ment of the public accounting firm should consider many things and find an alternative way to mitigate the effect of time budget pressure. Moreover, control related the auditor's job also needed.

Therefore, the result of this study has answered all the research question and the research objectives. Hence, this research provides the essential understandings which contribute to the literature of dysfunctional audit behavior. The researcher hopes that this research will encourage another researcher(s) to examine the research on this related topic further.

There are several limitations in this study that should be emphasized. First, the sample of this research is limited to only one profession and only from a specific region in Indonesia which is Jakarta. Subsequently, the results cannot be generalized to other business and another country or several areas of Indonesia. Thus, future research should examine the research model in different professional and other regions in Indonesia so that the result can be used universally. Second, this research only focuses on factors affecting professional skepticism. Meanwhile, the critical output of auditor is audit quality. Therefore, future research can add audit quality in the research model.

This study also provides a recommendation for future research. The survey of [6] showed that the effect of time budget pressure can vary on gender, position, experience. The study of [25] explained that females' auditor is paying more attention to detail than the male auditor, which create higher pressure on the female auditor. Meanwhile, according to [17], an auditor with lower position tends to face higher pressure than auditor in the higher position. Then, according to [9], an auditor with more working experience tends to be more tolerating to time pressure. Since this study examines the relationship between time budget pressure, auditor independence, and professional skepticism. Therefore, auditors' gender, position, and experience can be added to the research model. According to [6], time budget pressure is the cause of the public accountant firm want to reduce the audit fee. Therefore audit fee can be added for future research.

Moreover, [6] stated that time budget pressure will affect an auditor's well-being in term of job satisfaction, life satisfaction, and life balance. Hence, this study suggests future researchers examine the relationship between time budget pressure and auditor quality and expand the research area. Lastly, according to [26], auditor's time pressure will increase in the busy season period. Therefore busy season can be added for future research. In summary, since working with minimum time happens numerously in auditor job, the researcher hopes that future research could focus on the effect of time budget pressure to auditing practice. 


\section{REFERENCES}

[1] American Institute of Certified Public Accountants (AICPA). 1972. AU Section 110: Responsibilities and functions of the independent auditor. Accessed: 1 April 2018, https://www. aicpa.org/Research/Standards/AuditAttest/Do wnloadableDocuments/AU-00110.pdf.

[2] American Institute of Certified Public Accountants. 1992. Statement on Auditing Standards. https://www.aicpa.org/research/standards/auditattest/sas.html.

[3] Baron-Cohen S., Leslie A. M., and Frith U. (1985). Does the autistic child have a 'theory of mind'? Cognition, 21, 37-46.

[4] Bills, K. L., Swanquist, Q. T., and Whited, R. L. (2015). Growing pains: Audit quality and office growth. Contemporary Accounting Research, 33(1), 288-313.

[5] Bowrin, R. A., and King, J. (2010). Time pressure, task complexity, and audit effectiveness. Managerial Auditing Journal, 25(2), 160-181.

[6] Broberg, P., Torbjorn, T., Daniela, A., Niclas, G., and Ola, M. (2016). Explaining the influence of time budget pressure on audit quality in Sweden. Journal of Management and Governance, 14(4), 351-377.

[7] Chen, Q., Kelly, K., and Salterio, S. E. (2012). Do changes in audit actions and attitudes consistent with increased auditor scepticism deter aggressive earnings management? An experimental investigation. Accounting, Organizations and Society, 37(2), 95-115.

[8] Chiang, C. (2016). Conceptualizing the linkage between professional scepticism and auditor independence. Pacific Accounting Review, 28(2), 180-200.

[9] Cianci, A. M., and Bierstaker, J. (2009). Auditors' efficiency motivated evaluation. Advances in Accounting, 25(1), 20-27.

[10] Consideration of fraud in a financial statement audit. 1997a. Statement on Auditing Standards, 82.

[11] Consideration of fraud in a financial statement audit. 2002. Statement on auditing standards, 99.

[12] Coram, P., Ng, J., and Woodliff, D. R. (2004). The effect of misstatement on the propensity to commit reduced audit quality acts under time budget pressure. Auditing: A Journal of Practice \& Theory, 23(2), 159-167.

[13] Dillman, D. A., Mail and Internet Survey: The Tailored Design Method, Second Edition, John Wiley and Sons., New York, 2000.

[14] Dhar, R., and Nowlis, S. M. (1999). The effect of time pressure on consumer choice deferral. Journal of Consumer Research, 25, 369-384.
[15] Due care in the performance of work. 1997b. Statement on auditing standards, 1 .

[16] Due professional care in the performance of work. 2006a. AU Section 230. https://pcaobus. org/Standards/Archived/PreReorgStandards/P ages/AU230.aspx

[17] Ettredge, L. M., Bedard, C. J., and Johnstone, M. K. (2008). Empirical tests of audit budget dynamics. Behavioral Research in Accounting, 20(2), 1-18.

[18] Fornell, C., and Larcker, D. F. (1981). Evaluating structural equation models with observable variables and measurement error. Journal of Marketing Research, 18(1), 39-50.

[19] Grey, C. (1998). 'On being a professional in a "big six" firm'. Accounting, Organizations and Society, 23(5-6), 569-587.

[20] Gundry, C. L., and Liyanarachchi, A. G. (2007). Time budget pressure, auditors' personality type, and the incidence of reduced audit quality practices. Pacific Accounting Review, 19(2), 125-152.

[21] Hair, J. F., Black, W. C., and Babin, B. J. Multivariate Data Analysis: A Global Perspective, Prentice Hall, Upper Saddle River, 2010.

[22] Hair, J., T. Hult., C. Ringle., and M. Standart., A Primer on Partial Least Squares Structural Equation Modelling (PLS-SEM), Sage, Los Angeles, 2013.

[23] Hurtt, R. K. (2010). Development of a scale to measure professional skepticism. Auditing: A Journal of Practice \& Theory, 29(1), 149-171.

[24] Hurtt, R.K., Brown-Liburd, H., Earley, C.E., and Krishnamoorthy, G. (2013). Research on auditor professional skepticism: Literature synthesis and opportunities for future research. Auditing: A Journal of Practice and Theory, 32(1), 45-97.

[25] Ittonen, K., Va "ha "maa, E., and Va "ha "maa, S. (2013). Female auditors and accruals quality. Accounting Horizons, 27(2), 205-228.

[26] John T. S. and Scott L. S. (2002). The effect of the busy season workload on public accountants' job burnout. Behavioural Research in Accounting, 14(1), 223-245.

[27] Kelley, T., and Margheim, L. (1990). The impact of time budget pressure, personality, and leadership variables on dysfunctional auditor behavior. Auditing: A Journal of Practice \& Theory, 9(2), 21-42.

[28] Kruglanski, A. W., Webster, D. M. and Klem, A. (1993). Motivated resistance and openness to persuasion in the presence or absence of prior information. Journal of Personality and Social Psychology, 65(5), 861-876.

[29] Margheim L., Kelley, T., and Pattison, D. (2005). An empirical analysis of the effects of auditor time budget pressure and time deadline pressure. The Journal of Applied Business Research, 21(1), 23-36. 
[30] Mautz, R.K. and Sharaf, H.A., The Philosophy of Auditing, American Accounting Association Monograph No.6, Savasto, Florida Book, USA, 1961.

[31] McNair, C., The effects of budget pressure on audit firms: An empirical examination of the underreporting of chargeable time, Disertations and Theses, Columbia University., New York, 1987.

[32] Mehta, A. and Bhavani, G. (2017). Application of forensic tools to detect fraud: The case of Toshiba. Journal of Forensic and Investigative Accounting, 9(1), 692-710.

[33] Meneses, R. W. and Larkin, M. (2016). The experience of empathy: Intuitive, sympathetic, and intellectual aspects of social understanding. Journal of Humanistic Psychology, 57(1), 3-32.

[34] Naess, A., Skepticism: International Library of Philosophy and Scientific Method, Humanities Press., New York, 1969.

[35] Nelson, M. (2009). A model and literature review of professional skepticism in Auditing. Auditing: A Journal of Practice \& Theory, 28(2), 1-34.

[36] Obermiller, C., and E. R. Spangenberg. (1998). Development of scale to measure consumer skepticism towards advertising. Journal of consumer psychology, 7(2), 159-186.

[37] Otley, D. T., and Pierce, B. J. (1996). Auditor time budget pressure: Consequences and antecedents. Accounting, Auditing \& Accountability Journal, 9(1), 31-58.

[38] Pierce, B., and Sweeney, B. (2004). Costquality conflict in audit firms: An empirical investigation. European Accounting Review, 13(1), 415-441.

[39] Pierce, B., and Sweeney, B. (2006). Perceived adverse consequences of quality threatening behavior in audit firms. International Journal of Auditing, 10(1), 19-39.

[40] Public Company Accounting Oversight Board. (2004). An audit of internal control over financial reporting performed in conjunction with an audit of financial statements. https://pcaobus.org/Rulemaking/Docket008/20 04-03-09_Release_2004-001-all.pdf.
[41] Responsibility and function of the independent auditor. 1972. AU Section 110. https:// pcaobus.org/Standards/Archived/PreReorgSta ndards/Pages/AU110.aspx

[42] Sarstedt, M., Hair, J. F., Hopkins, L., and Kuppelwieser, V. G. (2014). Partial least squares structural equation modeling (PLS-SEM): An emerging tool in business research. European Business Review, 26(2), 106-121.

[43] Sekaran, U., and Bougie, R., Research Method for Business: A Skill-Building Approach, Sixth Edition, John Wiley \& Sons., UK, 2013.

[44] Sholihin, M., and Ratmono, D., Analisis SEMPLS dengan WarpPLS 3.0 untuk Hubungan Nonlinier dalam Penelitian Sosial dan Bisnis, Yogyakarta, 2013.

[45] Sikka, P. (2009). Financial crisis and the silence of the auditors. Accounting, Organizations and Society, 34(6-7), 868-873.

[46] Soobaroyen, T., and Chengabroyan, C. (2006). Auditors' perceptions of time budget pressure, premature sign offs and under-reporting of chargeable time: Evidence from a developing country. International Journal of Auditing, 10, 201-218.

[47] Sweeney, B., and Pierce, B. (2006). Good hours, bad hours and auditors' defence mechanisms in audit firms. Accounting, Auditing \& Accountability Journal, 19(6), 858-892.

[48] Tepalagul, N. and L. Lin. (2014). Auditor independence and audit quality: A literature review. Journal of Accounting, Auditing \& Finance, 30(1), 101-121.

[49] Williams, E.S., Konrad, T.R., Scheckler, W.E., Pathman, D.E., Linzer, M., McMurray, J.E., Gerrity, M. and Schwartz, M. (2001), "Understanding physicians' intentions to withdraw from practice: The role of job satisfaction, job stress, mental and physical health, Health Care Manage Review, 26(1), 7-19.

[50] Yuen, D. C. Y., Law, P. K. F., Lu, C., and Qi Guan, J. (2013). Dysfunctional auditing behaviour: Empirical evidence on auditors' behaviour in Macau. International Journal of Accounting \& Information Management, 21(3), 209-220. 